九州大学学術情報リポジトリ

Kyushu University Institutional Repository

\title{
Uptake of Dopamine and Subsequent Ultrastructural Changes in Gonadotrophs of the Laying Hen
}

Ishibashi, Toshiko

Laboratory of Animal Husbandry II, Faculty of Agriculture, Kyushu University

Takahara, Hitoshi

Laboratory of Animal Husbandry II, Faculty of Agriculture, Kyushu University

https://doi.org/10.5109/23816

出版情報：九州大学大学院農学研究院紀要. 30 (2/3)，pp. 107-111，1985-12. Kyushu University バージョン：

権利関係 : 
J. Fac. Agr., Kyushu Univ., 30 (2 . 3),107-111, 2 pls. (1985)

\title{
Uptake of Dopamine and Subsequent Ultrastructural Changes in Gonadotrophs of the Laying Hen
}

\author{
Toshiko Ishibashi* and Hitoshi Takahara \\ Laboratory of Animal Husbandry II, Faculty of Agriculture, \\ Kyushu University 46-06, Fukuoka 812
}

(Received July 10, 1985)

\begin{abstract}
Intraperitoneally injected dopamine was taken up selectively into gonadorophs of the laying hen and induced different changes in the ultrastructure of gonadotrophs according to the stages of the ovulatory cycle, i. e. the gonadotrophs exhibited an accumulation of secretory granules in the cytoplasm both at $18-19$ and 3-4 h before ovulation, whereas they showed a conspicuous decrease of secretory granules and also concentration of lysosomes nearby a mass of the granules at 7-8 $\mathrm{h}$ before ovulation. These results suggest that dopamine may play a role in inhibitory effects on the secretory activity of the laying hen gonadotrophs both by obstructing the discharge of secretory granules from the cells and by activating lysosomes which autophagocytise the granules within the cells.
\end{abstract}

\section{INTRODUCTION}

Histochemical fluorescence technique has revealed that the adenohypophyseal cells in several mammalian and avian species contain biogenic monoamines, can also take up their precursors and subsequently decarboxylate them, but the physiological role of these amines within the cells has not been elucidated (Partanen, 1978). Ishibashi and Takahara (1983) demonstrated the uptake of L-dopa (a precursor of dopamine, DA) by corticotrophs and gonadotrophs of the laying hen adenohypophysis using the formaldehydeinduced fluorescence method (Falck et al., 1962). After that, we confirmed the uptake of intraperitoneal DA by gonadotrophs of the laying hen with the above method and estimated the close relationship between the specific uptake of the DA by gonadotrophs and their secretory activity. Therefore, the aim of this study is to examine with a fluorescence microscope the uptake of DA by gonadotrophs of the laying hen after intraperitoneal DA injection at various stages of the ovulatory cycle, and with an electron microscope ultrastructural changes of the gonadotrophs.

\section{MATERIALS AND METHODS}

White leghorn hens of their first year of lay were caged individually and maintained under a lighting schedule of $14 \mathrm{~h}$ light and $10 \mathrm{~h}$ darkness. Their

* Present address: Department of Anatomy, Wakayama Medical College, Wakayama 640 
ovulation times were estimated, based on the previous oviposition times which had been recorded. Eighteen birds were divided equally into control and experimental birds were intraperitoneally injected with $100 \mathrm{mg}$ of $\mathrm{DA} / \mathrm{kg}$ body weight $1 \mathrm{~h}$ before killing. The birds of each group were killed at 18-19, 7-8 and 3-4 $\mathrm{h}$ before ovulation. The adenohypophysis was rapidly removed and cut into two pieces in mid saggital plane for fluorescence and electron microscopy.

\section{Fluorescence microscopy}

By the method of Falck et al. (1962), the tissue was rapidly frozen in isopentane precooled with dryice, freeze-dried for several days at $-40^{\circ} \mathrm{C}$ and exposed to formaldehyde vapour (about $60 \%$ relative humidity) for $1 \mathrm{~h}$ at $+80^{\circ} \mathrm{C}$, then it was embedded in paraffin wax in vacuo, sectioned at $4 \mu \mathrm{m}$ and mounted in xylen. The sections were examined with a Nikon Fluophot VFD. TR fluorescence microscope.

\section{Electron microscopy}

Another tissue was immersed in $1 \%$ paraformaldehyde - $3 \%$ glutaraldehyde fixative in $0.2 \mathrm{M}$ cacodylate buffer $(\mathrm{pH} 7.4)$ at room temperature for 20 to $30 \mathrm{~min}$. before cutting into small pieces and then fixed with the same fixative overnight. After rinsing with $0.1 \mathrm{M}$ cacodylate buffer ( $\mathrm{pH} 7.4$ ), the tissues were postfixed with $1.3 \%$ osmium tetroxide in the same buffer for $2 \mathrm{~h}$, dehydrated with acetone and embedded in epoxy resin (Quetol-812). Thin sections (ca. $60 \mathrm{~nm}$ ) were made on Porter-Blum MT-l ultramicrotome, doubly stained with uranyl and lead acetate, and examined with an Hitachi HS-9 electron microscope $(75 \mathrm{kV})$.

\section{RESULTS}

\section{Fluorescence microscopic observations}

In untreated control birds, fluorescent gonadotrophs were not observed at any stages of the ovulatory cycle. In the experimental birds, however, gonadotrophs especially located in the caudal lobe exhibited strong fluorescence (deep green) at the vascular pole of their cytoplasm. The number of these cells differed in different stages of the ovulatory cycle, i. e. many fluorescent cells aggregated densely at the sides facing sinusoidal capillaries at $3-4 \mathrm{~h}$ before ovulation (P1. I, Fig. 1), but a considerable number of the cells lied scattered at 7-8 $\mathrm{h}$ before ovulation (Pl. I, Fig. 2).

\section{Electron microscopic observations}

Gonadotrophs of the control birds were round or oval in shape and located adjacent to the sinusoidal capillaries. The Golgi apparatus were prominent and several lysosomes often existed near them. The endoplasmic reticuli like small sacs and round mitochondria were distributed throughout the cytoplasm. Dense spherical secretory granules were stored characteristically at the vascular pole of the cytoplasm. They varied in the amount and distribu- 
tion with stages of the ovulatory cycle, i. e. they were rather few at 18-19 and 3-4 h before ovulation (Pl. I, Fig. 3), whereas they were abundant and densely packed within almost whole cytoplasm at $7-8 \mathrm{~h}$ before ovulation (P1. I, Fig. 4).

In gonadotrophs of the experimental birds, secretory granules accumulated at the vascular pole and lysosomes existed nearby Golgi field at the opposite pole away from the mass of the granules at 18-19 and 3-4 h before ovulation (Pl. II, Fig. 5). In contrast, at 7-8 h before ovulation, the granules of gonadotrophs markedly decreased and several lysosomes moved near or within the mass of the granules and often autophagocytised the granules (Pl. II, Fig. 6 and inset). Also the cisternae of the endoplasmic reticulum slightly dilated and the Golgi apparatus were less prominent or thread-like.

\section{DISCUSSION}

In mammals, distribution of aminergic neurons in the brain and effects of amines on the secretory activity of the adenohypophysis have been well discussed (Schneider and McCann, 1969, Kamberi et al., 1970, MacLeod and Leh. meyer, 1974, Brown et al., 1976, Weiner and Ganong, 1978, Sawyer, 1979) ; out of various aminergic pathways, the tuberoinfundibular dopaminergic pathway ending in the external layer of the median eminence has a close relation, through release of DA into the portal blood or through axo-axonal interaction with neurosecretory terminals in the median eminence, with the control of the adenohypophyseal secretory activity.

Similarly in birds, hypothalamic amines appear to participate in regulation of the adenohypophyseal hormone secretion (Scanes et al., 1982), although distribution of aminergic neurons in the hypothalamus considerably differs from that in mammals (Hartwig, 1982). The possible direct action of DA on the gonadotrophs of the adenohypophysis in the laying hen is discussed from a standpoint of the functional morphology, as follows:

Intraperitoneally injected DA was specifically taken up by gonadotrophs, i. e. since the fluorescent part within the cytoplasm of gonadotroph corresponded ultrastructurally to the side where secretory granules were accumulated, it is suggested that DA comes to be contained in secretory granules. Conspicuous accumulation of secretory granules in gonadotrophs of the hens treated with DA at 18-19 and 3-4 h before ovulation indicated that DA existing within secretory granules inhibited the discharge of the granules from the cells. A possibility has been presumed in the rat that DA inhibiting PRL secretion is internalized into the PRL secretory granules (Nansel et al., 1979). In addition, it is considered that the internalization and incorporation of DA into PRL secretory granules may be a component of the overall inhibitory action of DA on PRL secretion (Gudelsky et al., 1980). Therefore, our observations revealed that DA uptaken by gonadotrophs of the laying hen has an inhibitory effect on the hormone secretion.

Gonadotrophs in the control birds at 7-8 $\mathrm{h}$ before ovulation stored a large amount of secretory granules. Those in the birds treated with DA at the 
same stage, however, exhibited an aggregation of lysosomes nearby the mass of secretory granules, uptake of secretory granules by these lysosomes and consequent decrease of secretory granules. With respect to the function of lysosomes incorporate and degrade secretory granules to regulate the secretory process (Smith and Farquhar, 1966). Accordingly, our results demonstrated that DA causes apparent inhibitory effects, i. e. activation of lysosomes and subsequent removal of secretory granules, on the secretory granule of gonadotrophs. In this connection, Harrison (1979) has reported that intraperitoneally injected L-dopa may play a role in the regulation of the secretory activity of the adenohypophysis in the male Chinese quail by mediating the lysosomal activity.

In the present study, the morphological findings on the secretory activity of the gonadotrophs, i. e. the discharge obstruction of secretory granules from the cells and the autophagocytosis of secretory granules by lysosomes, supported the inhibitory effect of DA on the gonadotrophin serection in the laying hen.

\section{ACKNOWLEDGEMENTS}

We thank Professor T. A. Uchida and Dr. T. Mōri of Zoological Laboratory for useful suggestions and for technical advice, respectively, and Professor E. W. Jameson, Jr., University of California for comments on the manuscript.

\section{REFERENCES}

Brown, G. M., P. Seeman and T. Lee 1976 Dopamine/neuroleptic receptor in basal hypothalamus and pituitary. Endocrinol., 99 : 1407-1410

Falck, B., N.-A. Hillarp, G. Thieme and A. Torp 1962 Fluorescence of catecholamines and related compounds condensed with formaldehyde. J. Histochem. Cytochem., 10: 348 354

Gudelsky, G. A., D. D. Nansel and J. C. Porter 1980 Uptake and processing of dopamine by cells of the anterior pituitary gland. Endocrinol., 107: 30-34

Harrison, F. 1979 The effect of L-dopa on the ultrastructure of the adenohypophysis of Chinese quail, Excalfactoria chinensis. Cell Tissue Res., 198 : $521-526$

Hartwig, H. -G. 1982 Hypothalamic distribution of monoamine-containing neurons in homeothermic vertebrates. In 'Neurosecretion", ed. by D. S. Farner and K. Lederis, Plenum Press, New York, London, pp. 93-103.

Ishibashi, T. and H. Takahara 1983 A fluorescenece histochemical study of the catecholamine-containing cells in the adenohypophysis of the domestic fowl (Gallus domesticus). Sci. Bull. Fac. Agr., Kyushu Univ., 38 : 9-13

Kamberi, I. A., R. S. Mical and J. C. Porter 1970 Effect of anterior pituitary perfusion and intraventricular injection of catecholamines and indolamines on LH release. Endocrinol., 81: I-12

MacLeod, R. M. and J. E. Lehmeyer 1974 Studies on the mechanism of the dopaminemediated inhibition of prolactin secretion. Endocrinol., 94: 1077-1085

Nansel, D. D., G. A. Gudelsky and J. C. Porter 1979 Subcellular localization of dopamine in the anterior pituitary gland of the rat: apparent association of dopamine with pro- 
lactin secretory granules. Endocrinol., 105: 1073-1077

Partanen, S. 1978 Carbonyl compound-induced fluorescence of biogenic monoamines in the endocrine of the hypophysis. Progr. Histochem. Cytochem., 10: 1-19

Sawyer, C. H. 1979 Brain amines and pituitary gonadotrophin secretion. Can. J.Physiol. Pharmacol., 51: 667-680

Scanes, C. G., J. Rabii and F. C. Buonomo 1982 Brain amines and the regulation of anterior pituitary secretion in the domestic fowl. In "Aspects of Avian EndocrinolWY", ed. by C. G. Scanes, M. A. Ottinger, A. D. Kenny, J. Balthazart, J. Cranshaw and I. Chester Jones, Texas Tech. Press, Lubbock, Texas, pp. 13-31

Schneider, H. P. G. and S. M. McCann 1969 Possible role of dopamine as transmitter to promote discharge of LH-releasing factor. Endocrinol., 85: 121-132

Smith, R. E. and M. G. Farquhar 1966 Lysosome function in the regulation of the secretory process. in cells of the anterior pituitary gland. J.Cell Biol, 31: 319-347

Weiner, R. I. and W. F. Ganong 1978 Role of brain monoamines and histamine regulation of anterior pituitary secretion. Physiol. Rev., 58: 905-976 


\title{
Explanation of Plates I, II
}

\begin{abstract}
Abbreviations : CAP, capillaries; ER, endoplasmic reticulum; G, Golgi field; L, lysosome; M, mitochondria; N, nucleus; PCS, pericapillary space; SG, secretory granules.
\end{abstract}

\section{Plate I}

Figs. 1, 2. Fluorescence micrographs showing the caudal lobe of the laying hen adenohypophysis after intraperitoneal injection of DA at 3-4 h (Fig. 1) and 7-8 h (Fig. 2) before ovulation.

Fig. 1. Aggregation of fluorescent gonadotrophs at the sides facing sinusoidal capillaries.

Fig. 2. Scattering of fluorescent gonadotrophs.

Figs. 3, 4. Electron micrographs of gonadotrophs in the control birds at 18-19 h (Fig. 3) and 7-8 h (Fig. 4) before ovulation.

Fig. 3. Location of secretory granules at the vascular pole.

Fig. 4. Note densely packed secretory granules within almost whole cytoplasm. 

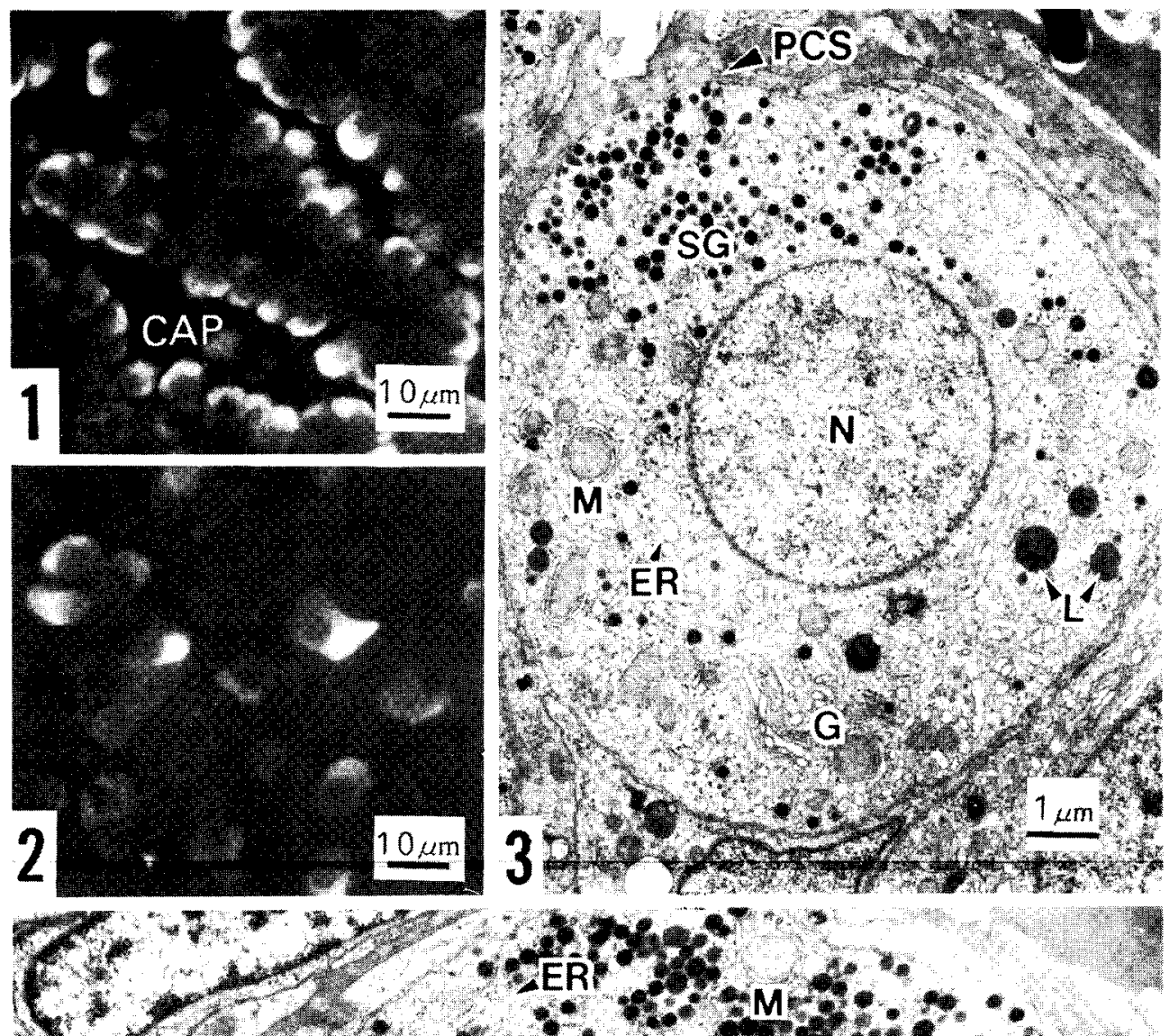
3.

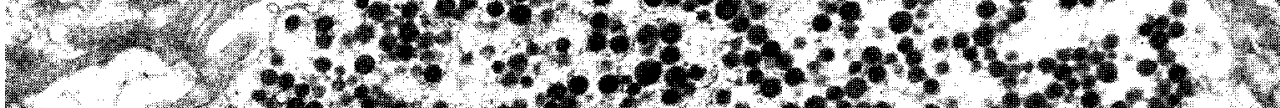

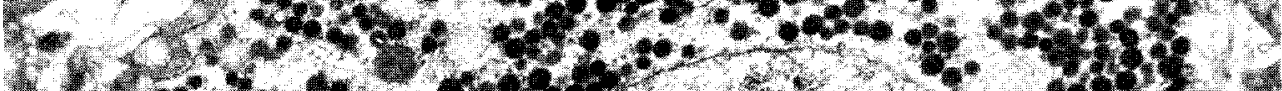

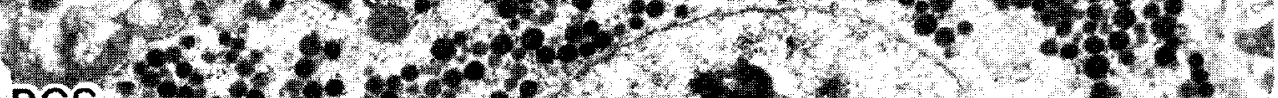

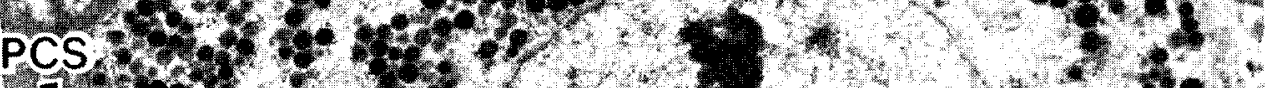

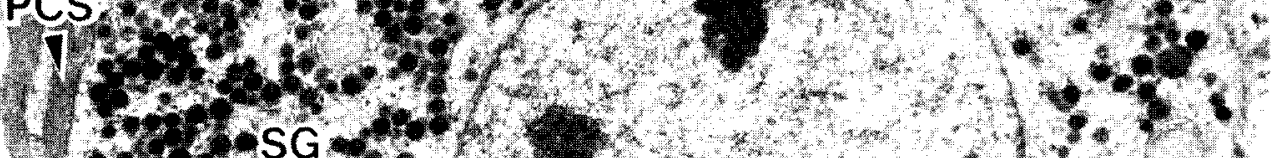

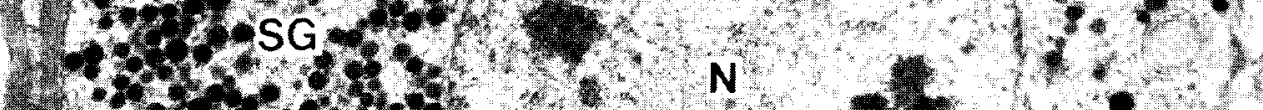

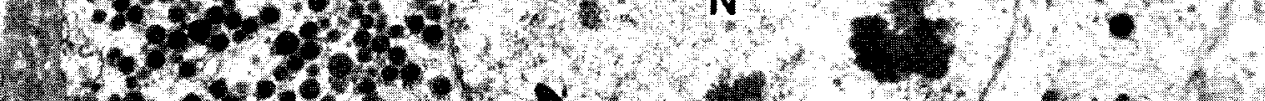

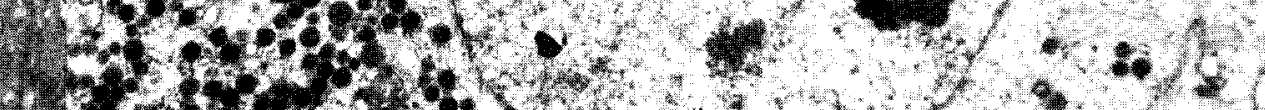

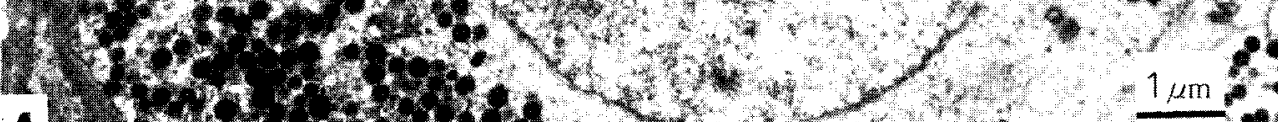

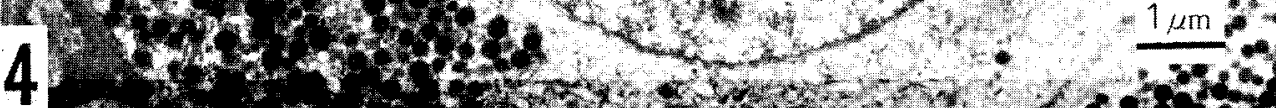




\section{Plate II}

Figs. 5, 6. Electron micrographs showing gonadotrophs of the hens treated with DA at 18-19 h (Fig. 5) and 7-8 h (Fig. 6) before ovulation.

Fig. 5. Highly accumulated secretory granules at the opposite pole and lysosomes nearby Golgi field at the opposite pole.

Fig. 6. Note the aggregation of lysosomes near the mass of secretory granules and an autophagocytic body containing a secretory granule (inset). 

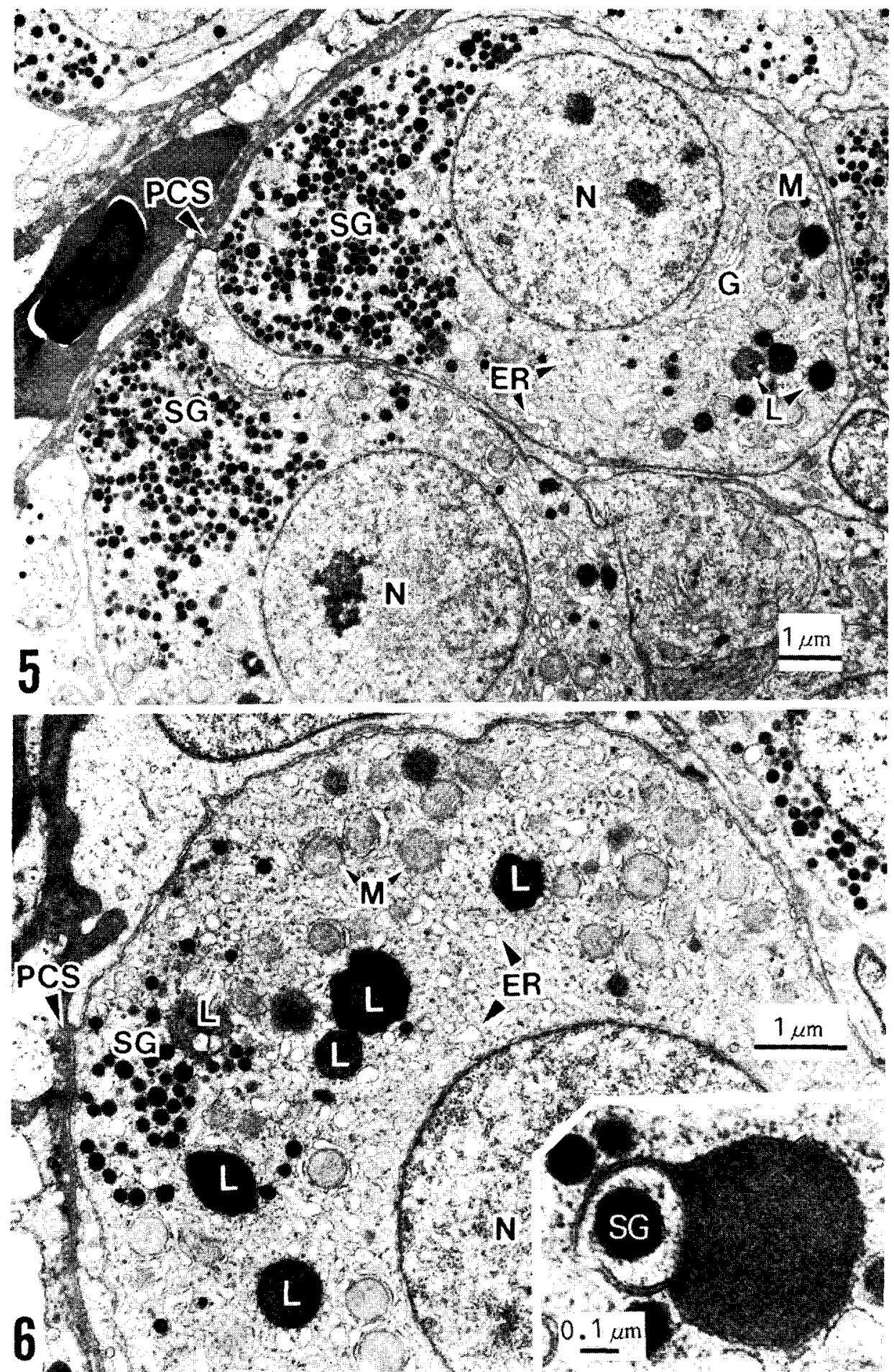